\title{
The Effect of Long-Term Antihypertensive Therapy on the Change in Secretion and Calcium, Bicarbonate and Phosphate Ion Concentration in Non-Stimulated and Stimulated Saliva
}

\section{Učinak dugotrajne antihipertenzivne terapije na promjenu izlučivanja i koncentraciju kalcijevih, bikarbonatnih i fosfatnih iona u nestimuliranoj i stimuliranoj slini}

\footnotetext{
${ }^{1}$ Department of Endodontics, Medical Faculty, University of Banja Luka, Bosnia and Herzegovina Zavod za endodonciju Medicinskog fakulteta Sveučilišta Banja Luka, Bosna i Hercegovina

${ }^{2}$ Department of Endodontics and Restorative Dentistry, School of Dental Medicine, University of Zagreb, Croatia Zavod za endodonciju i restaurativnu stomatologiju Stomatološkog fakulteta Sveučilišta u Zagrebu, Hrvatska

${ }^{3}$ Department of Parodontology and Oral Disease, Medical Faculty, University of Banja Luka, Bosnia and Herzegovina Zavod za parodontologiju i bolesti usta Medicinskog fakulteta Sveučilišta Banja Luka, Bosna i Hercegovina

${ }^{4}$ Department of Prosthetics, Medical Faculty, University of Banja Luka, Bosnia and Herzegovina

Zavod za protetiku Medicinskog fakulteta Sveučilišta Banja Luka, Bosna i Hercegovina
}

\section{Abstract}

Objective: The aim of this study was to evaluate the amount of saliva secreted and calcium, bicarbonate, and phosphate ion concentration in patients receiving antihypertensive for five years or over five years (patient group) and in healthy patients (control group). Material and methods: The patient or experimental group included 31 subjects who were admitted to a cardiovascular clinic and had been receiving an antihypertensive drug therapy for more than five years. The control group included 31 healthy subjects. The measured amount of saliva was further used to determine the calcium, phosphate and bicarbonate ion concentration values. Calcium and phosphate ions were determined spectrophotometrically, while bicarbonate ions were determined by titration. Results: A two-waytest (Student's test) was used to compare the values of variables. The amount of excreted saliva was statistically significantly lower in the patient group in non-stimulated $(1.739 \mathrm{~mL} / 5 \mathrm{~min})$ and stimulated saliva (3.594 mL/5 min). Calcium ion concentration was statistically significantly lower in patient group in resting saliva $(6.143 \mathrm{mg} / \mathrm{dL})$. Bicarbonate and phosphate ion concentration in patient group was statistically significantly higher in non-stimulated (bicarbonate ion $=14.041 \mathrm{mmol} / \mathrm{L}$, phosphate ion $=2.818 \mu \mathrm{mol} / \mathrm{L}$ ) and stimulated saliva (bicarbonate ion $=10.872 \mathrm{mmol} / \mathrm{L}$, phosphate ion $=1.454$ $\mu \mathrm{mol} / \mathrm{L}$ ), respectively. Conclusion: A reduced amount of saliva and calcium ion concentration indicates the possibility of a higher frequency of hard dental tissue demineralization process. On the contrary, the increase in the phosphate and bicarbonate ion concentration in the patient group affects the regulation of acid-base balance, thus having a preventive effect.
Received: August 4, 2020

Accepted: November 16, 2020

Address for correspondence Božidar Pavelić, Full Professor, DMD, $\mathrm{MS}, \mathrm{PhD}$;

University of Zagreb School of Dental Medicine

Department of Endodontics and Restorative Dentistry

Gundulićeva 5, HR10 000 Zagreb,

Croatia

Phone: +385 (0) 14802136

Fax: +385 (0)1 4802159

pavelic@sfzg.hr

Key words

Antihypertensive Agents; Long Term Adverse Effects; Salivation; Bicarbonates; Calcium; Phosphorus

\section{Introduction}

Saliva has several different types of functions (antibacterial properties, digestion, cleansing, buffering, lubrication, etc.,) which play an important role in maintaining both oral and overall health of the body $(1,2)$. Saliva secretion is controlled by three basic centers: primary (localized in the medulla oblongata), secondary (thalamus), and tertiary salivation center (opercula- insular zone of the cerebral cortex) (3). Based on the manner of production and excretion, mixed saliva is divided into stimulated saliva and resting saliva. Stimulated mixed saliva occurs as a result of the effect of the most diverse fac-
Uvod

Slina ima više različitih funkcija (antibakterijska, probavna, čišćenje, puferiranje, podmazivanje, itd.) koje su važne u održavanju zdravlja usne šupljine i cjelokupnog organizma $(1,2)$. Izlučivanje sline kontroliraju tri osnovna centra: primarni (smješten u produženoj moždini), sekundarni (u talamusu) i tercijarni centar za salivaciju (operkulo-insularna zona moždane kore) (3). Na temelju načina stvaranja i izlučivanja, sveukupno stvorena slina dijeli se na stimuliranu i nestimuliranu. Stimulirana slina nastaje kao rezultat utjecaja različitih čimbenika koji uzrokuju njezino pojačano izluči- 
tors, which act directly in the oral environment on numerous and diverse receptors, and/or indirectly through the sense of sight, hearing or smell, thus causing its secretion to be enhanced. Resting mixed saliva is produced as a secretion product of the entire glandular apparatus of the oral cavity in conditions when there is no external stimulus for its creation.

The acidity of the oral cavity environment is closely related to the amount and the chemical composition of the secreted mixed saliva. The $\mathrm{pH}$ measurement of mixed saliva has shown a wide range from the most acidic $(\mathrm{pH}=6.1)$ to alkaline $(\mathrm{pH}=7.8)$. Acidity of saliva is also associated with the measurement period (during day or night), as well as with the volume of salivary secretion, i.e. whether it is stimulated or resting salivation and it is important in patients undergoing radiotherapy $(4,5)$.

Bicarbonate buffer is excreted in enhanced concentration during stimulated salivation when it represents the dominant buffer. Due to the multiplier effect of enhanced concentration of this buffer, mixed saliva becomes alkaline, reaching a $\mathrm{pH}$ of 7.8. In such alkalization conditions, and due to the effect on the acid products present in saliva, it can be considered as a precautionary measure in preventing demineralization of the hard-dental tissues' surface $(1,5)$.

Phosphate buffer is the basis of the buffer system in resting saliva. It is extremely important in the physiological processes of resting saliva (during 22 hours in a day), and in the period when there is no stimulated saliva secretion. For remineralization processes of the surfaces of hard-dental tissues, apart from the buffer, the amount of calcium and phosphate ions present in the saliva is pivotal $(6,7)$. A high concentration of these ions in saliva prevents the demineralizing effect of water while remineralizing the enamel's damaged surface at the same time.

Different local and systemic diseases may be the reason for qualitative and quantitative changes in salivary secretion (Parkinson's disease, Alzheimer's disease, glandular infections, tumors and use of certain drugs) $(8,9)$. The drugs that most commonly cause problems in the qualitative and quantitative secretion of saliva belong to different groups such as antihypertensives, antihistamines, opioids, and antidepressants $(10,11)$.

Antihypertensives may be divided into two broad groups: the first group of drugs which directly or indirectly block the renin-angiotensin system (the predominant effect is to cause vasodilatation) and the second group of drugs works by increasing water and sodium excretion (diuretics and calcium channel blockers). Different groups of drugs (i.e. inhibitors of the angiotensin converting enzyme, angiotensin receptor blockers, calcium channel blockers, thiazide diuretics), in addition to the antihypertensive effect, can also have an effect on other systemic parts of the human body, as well as on the qualitative and quantitative properties of the stimulated and non-stimulated saliva (12).

This study aimed to determine changes in the amount of saliva excreted and calcium, bicarbonate and phosphate ion concentration in stimulated and resting saliva in patients on long-term antihypertensive therapy (longer than five years), and to compare them with findings in a healthy population. vanje djelujući izravno u oralnom okružju na mnogobrojne i raznolike receptore $\mathrm{i} / \mathrm{ili}$ neizravno putem osjeta vida, sluha ili mirisa. Nestimulirana slina nastaje kao produkt izlučivanja cijeloga žljezdanog aparata usne šupljine u uvjetima kada nema vanjskog podražaja za njezino stvaranje.

Kiselost u usnoj šupljini usko je povezana s količinom i kemijskim sastavom izlučene sline. Mjerenje $\mathrm{pH}$ sline pokazalo je širok raspon - od najkiselijega $(\mathrm{pH}=6,1)$ do alkalno$\mathrm{ga}(\mathrm{pH}=7,8)$. Kiselost sline također je povezana s razdobljem mjerenja (danju ili noću) te $s$ volumenom izlučene sline, $t \mathrm{j}$. radi li se o stimuliranoj ili nestimuliranoj slini, što je iznimno važno za pacijente na radioterapiji $(4,5)$.

Bikarbonatni pufer izlučuje se u pojačanoj koncentraciji tijekom stimuliranog izlučivanja sline kada je dominantni pufer. Zbog multiplicirajućeg učinka pojačane koncentracije toga pufera slina postaje alkalna te doseže $\mathrm{pH}$ od 7,8. U takvim uvjetima alkalizacije i zbog učinka na kisele produkte prisutne u slini, može se smatrati preventivnom mjerom u sprječavanju demineralizacije površine tvrdoga zubnog tkiva $(1,5)$.

Fosfatni pufer osnova je puferskog sustava nestimulirane sline. Iznimno je važan u fiziološkim procesima nestimulirane sline (tijekom 22 sata na dan), odnosno u razdoblju kada nema stimuliranog izlučivanja sline. Za procese remineralizacije na površini tvrdoga zubnog tkiva, osim pufera, ključna je količina kalcijevih i fosfatnih iona u slini $(6,7)$. Visoka koncentracija tih iona u slini sprječava demineralizirajući učinak vode, istodobno remineralizirajući oštećenu površinu cakline.

Različite lokalne i sistemske bolesti mogu biti razlog za kvalitativne i kvantitativne promjene u izlučivanju sline (Parkinsonova bolest, Alzheimerova bolest, infekcije žlijezda, tumori i uporaba određenih lijekova) $(8,9)$. Lijekovi koji najčešće uzrokuju probleme u kvalitativnom i kvantitativnom izlučivanju sline pripadaju različitim skupinama kao što su antihipertenzivi, antihistaminici, opioidi i antidepresivi (10, $11)$.

Antihipertenzivi se mogu podijeliti u dvije velike skupine - u prvu su uvršteni lijekovi koji izravno ili neizravno blokiraju renin-angiotenzinski sustav (osnovni učinak jest postići vazodilataciju), a u drugoj su lijekovi koji povećavaju izlučivanje vode i natrija (diuretici i blokatori kalcijevih kanala). Različite skupine lijekova (inhibitori enzima koji djeluju na angiotenzin, blokatori angiotenzinskih receptora, blokatori kalcijevih kanala, tiazidni diuretici), osim antihipertenzivnog učinka, mogu utjecati i na druge sustave u organizmu te na kvalitativna i kvantitativna svojstva stimulirane i nestimulirane sline (12).

Cilj ovoga rada bio je utvrditi promjene u količini izlučene sline te u koncentraciji kalcijevih, bikarbonatnih i fosfatnih iona u stimuliranoj i nestimuliranoj slini bolesnika na dugotrajnoj antihipertenzivnoj terapiji (dulje od pet godina) te ih usporediti s nalazima u zdravoj populaciji. 


\section{Material and methods}

The study included 62 subjects divided into two groups: patient and control. The patient or experimental group included 31 (18 males, 13 females) subjects who were admitted to a cardiovascular clinic and who had been receiving antihypertensive drug therapy for more than five years. Twelve patients used a combination of beta-adrenergic blockers with ACE inhibitors, ten patients were on beta-adrenergic blockers and diuretics, while the remaining nine patients used a calcium antagonist in therapy of hypertension. The control group included 31 healthy subjects (13 males, 18 females). The study was conducted at the Clinic center and the Biological laboratory of the Faculty of Natural Sciences and Mathematics University of Banja Luka.

The patient group inclusion criteria were as follows: patients diagnosed with hypertension, patients who had been only on antihypertensive therapy for five years or more, hospitalized patients under medical supervision, patients without disease or clinical condition that could affect the qualitative and quantitative characteristics of salivation.

The patient group exclusion criteria were as follows: patients with occasional manifestations of hypertension, patients receiving the antihypertensive therapy occasionally or those receiving it less than five years, patients with disease or clinical condition that could affect the qualitative and quantitative characteristics of salivation.

The control group inclusion criteria were as follows: healthy patients with physiological pressure; patients who were not receiving any therapies..

The control group exclusion criteria were as follows: patients taking occasional antihypertensive drugs or any therapy that may affect the parameters being evaluated.

Each of the subjects received an information form, based on which they voluntarily consented for participation. The study was approved by the Ethics Committee of the Clinic center in Banja Luka, under the no. 01-5-355.2/12, and adhered to the principles outlined in the Declaration of Helsinki.

\section{Sample collection}

After the health history had been taken and processed, the extraoral and intraoral examinations were completed, and the resting and stimulated saliva sampling was done.

Non-stimulated and stimulated saliva samples of the patient were collected before breakfast, without taking any food or drinks previously, and without oral hygiene between 6.30 a.m. and 7.30 a.m. While preparing to take a sample, the patient was seated in a chair with the head slightly tilted forward, with relaxed arms and shoulders.

Non-stimulated saliva was collected in the mouth for five minutes, spat into a sterile measuring cylinder and closed. Each sample was marked with the letter $\mathrm{N}$ (non-stimulated, i.e. resting) and identified by an ordinal number from 1 to 31 .

Stimulated saliva was collected from patients after they had been chewing a paraffin ball $(8 \mathrm{~mm}$ in diameter) for 5 minutes, thus stimulating saliva secretion. The saliva obtained by stimulation was spat into a sterile measuring cyl-

\section{Materijal i metode}

Studija je obuhvatila 62 ispitanika koji su bili razvrstani u dvije skupine - u prvoj su bili pacijenti, a druga je bila kontrolna. Pacijent ili eksperimentalna skupina obuhvaćala je 31 ispitanika (18 muškaraca, 13 žena) koji su bili hospitalizirani u Kardiovaskularnoj klinici i uzimali su antihipertenzivnu terapiju lijekovima pet i više godina. Dvanaestorici bolesnika propisana je kombinaciju beta-adrenergičkih blokatora $s$ ACE inhibitorima, deset je uzimalo beta-adrenergičke blokatore i diuretike, a preostalih devet antagonist kalcija u terapiji hipertenzije. Kontrolna skupina obuhvaćala je 31 zdravu osobu (13 muškaraca, 18 žena). Istraživanje je provedeno u Kliničkom centru i u Biološkom laboratoriju Prirodno-matematičkog fakulteta Sveučilišta u Banjoj Luci.

Kriteriji za uključivanje u prvu skupinu bili su: pacijenti s dijagnozom hipertenzije, pacijenti koji su pet i više godina bili na antihipertenzivnoj terapiji, hospitalizirani pacijenti pod liječničkim nadzorom, pacijenti bez bolesti ili kliničkoga stanja koji bi mogli utjecati na kvalitativne i kvantitativne karakteristike izlučivanja sline.

Kriteriji za izuzeće iz skupine bolesnika bili su sljedeći: pacijenti s povremenim nalazima hipertenzije, pacijenti kojima je ordinirana antihipertenzivna terapija povremeno ili kraće od pet godina, bolesnici s bolešću ili kliničkim stanjem koje može utjecati na kvalitativne i kvantitativne značajke izlučivanja sline.

Kriteriji za uključivanje u kontrolnu skupinu bili su: zdravi ispitanici s fiziološkim tlakom, ispitanici koji nisu ni na kakvoj terapiji..

Kriteriji za izuzeće iz kontrolne skupine bili su sljedeći: pacijenti koji povremeno uzimaju antihipertenzivne lijekove, ili bilo koju terapiju koja može utjecati na parametre istraživanja u studiji.

Svaki ispitanik dobio je informativni obrazac te je potpisom potvrdio dobrovoljno sudjelovanje u studiji. Studiju je, poštujući načela Helsinške deklaracije, odobrilo Etičko povjerenstvo Kliničkoga centra u Banjoj Luci pod brojem 015-355.2/12.

\section{Prikupljanje uzoraka}

Nakon provjere anamnestičkih podataka te završetka ekstraoralnog i intraoralnog pregleda, uzeti su uzorci stimulirane i nestimulirane sline.

Uzorci nestimulirane i stimulirane sline uzimani su od ispitanika prije doručka, između 6,30 i 7,30 sati, prije čega nisu smjeli ništa ni pojesti ni popiti, niti obaviti higijenu usne šupljine. Tijekom pripreme za uzimanje uzorka pacijent je sjedio na stolcu s glavom lagano nagnutom prema naprijed te $s$ opuštenim rukama i ramenima.

Nestimulirana slina skupljala se u ustima pet minuta te zatim ispljunula u sterilni mjerni cilindar i zatvorila. Svaki je uzorak označen slovom N (nestimulirana) i rednim brojem od 1 do 31.

Stimulirana slina skupljana je od ispitanika nakon što su 5 minuta žvakali parafinsku kuglicu (promjera $8 \mathrm{~mm}$ ), stimulirajući tako izlučivanje sline. Slina dobivena stimulacijom ispljunuta je u sterilni mjerni cilindar i zatvorena. Uzorci dobiveni od svakog ispitanika označeni su brojevima od 1 do 31 
inder and closed. The samples obtained were marked with numbers from 1 to 31 and with letter $S$ (stimulated) for each patient.

During their transport to the laboratory (10 minutes), the samples were stored in a mobile refrigerator at a temperature of $4{ }^{\circ} \mathrm{C}$ until analyzed. The saliva sample obtained was poured into a glass measuring cylinder (graduated by $1 \mathrm{ml}$ ).

\section{Sample analysis}

The measured amount of saliva was recorded and divided by 5 to obtain the value of a milliliter of saliva per minute, and the final result was recorded in the questionnaire prepared. The measured amount of saliva was further used to determine the calcium, phosphate and bicarbonate ion concentration values. Calcium and phosphate ions were determined spectrophotometrically, while bicarbonate ions were determined by titration.

Calcium ion concentration was determined by the reaction of saliva sample and calcium arsenazo III reagent (2,2' -[(1,8-Dyhydroxy-3,6-disulfonaphthylene-2,7-bisazo)] bisbenzenearsonic acid), 2,7-Bis (2-arsonophenylazo) chromotropic acid, in such a way that $1 \mathrm{ml}$ arsenazo III reagent was added to $10 \mu \mathrm{L}$ of saliva, mixed and left for 3 minutes at room temperature $\left(20-25^{\circ} \mathrm{C}\right)$. After that, spectrophotometric measurement was performed with UV -1800 Shimadzu Spectrophotometer (Shimadzu Corporation, Kyoto, Japan) at $650 \mathrm{~nm}$ wavelength and obtained values were read on a spectrophotometer. The color intensity was directly proportional to calcium concentration in the saliva sample. The obtained values were entered in a formula (13):

calcium concentration $=\mathrm{SA}$ Abs $/ \mathrm{ST}$ Abs $\times 10=\mathrm{mg}$ calcium $/$ dL.

\section{sample absorbance $\times 10$}

standard absorbance

SA Abs - sample absorbance

ST Abs - standard absorbance

The obtained values were tabulated.

The phosphate concentration was determined by molybdenum reaction by Goldenberg and Fernandez's spectrophotometric method, modified by Bardow et al. (13). Buffer (reaction mixture consisting of $10 \%$ trichloroacetic acid (TCA), $1 \%$ urea and 3\% Mohr's salt) was added to saliva. The buffer was prepared directly in the laboratory. After 10 minutes, centrifugation was performed (Tehtnica Centric 200R, Domel, Železniki, Slovenia) at $5000 \mathrm{rpm}$. It separates the supernatant and adds concentrated sulfuric acid and $4.5 \%$ ammonium molybdate to the supernatant. The preparation was kept for 20 minutes at room temperature and then the absorbance was spectrophotometrically measured at $700 \mathrm{~nm}$. The standard curve was made in the range from 0 to $10 \mu \mathrm{mol} / \mathrm{L}$ of phosphate.

Bicarbonate concentration is determined by titration with $0.1 \mathrm{M} \mathrm{HCl}$ ranging from $\mathrm{pH} 7$ to $\mathrm{pH} 3$, by adding $\mathrm{HCl}$ to the sample in a volume of $100 \mu \mathrm{L}$. Titrated saliva was measured in the said solution and each value was recorded. After the measurement, it was entered into the formula and final value was obtained. The formula used for calculating bicarbonate was: i slovom $S$ (stimulirana).

Tijekom transporta u laboratorij (10 minuta) uzorci su se čuvali u mobilnom hladnjaku na temperaturi od $4{ }^{\circ} \mathrm{C}$ do daljnjega provođenja postupka. Dobiveni uzorak sline uliven je u staklenu mjernu menzuru (stupnjevana po $1 \mathrm{~mL}$ ).

\section{Analiza uzoraka}

Izmjerena količina sline zabilježena je i podijeljena s 5 da bi se dobila vrijednost mililitra izlučene sline u minuti, a konačni rezultat zabilježen je u pripremljenom upitniku. Izmjerena količina sline dalje je korištena za određivanje vrijednosti koncentracije kalcijevih te fosfatnih i bikarbonatnih iona. Koncentracija kalcijevih i fosfatnih iona odredivala se spektrofotometrijski, a koncentracija bikarbonatnih iona titracijom.

Koncentracija kalcijevih iona određena je reakcijom uzorka sline i kalcijeva arsenazo III reagensa [2,2' - (1,8-dihidroksi-3,6-disulfonaftilen-2,7-bisazo) bisbenzensarzonska kiselina] te 2,7 -Bis (2-arsonofenilazo) kromotropne kiseline, na način da se $1 \mathrm{~mL}$ arsenazo III reagensa doda u $10 \mu \mathrm{L}$ sline, pomiješa i ostavi tri minute na sobnoj temperaturi $(20-25$ $\left.{ }^{\circ} \mathrm{C}\right)$. Nakon toga provedeno je mjerenje spektrofotometrom UV-1800 Shimadzu (Shimadzu Corporation, Kjoto, Japan) na valnoj duljini od $650 \mathrm{~nm}$ na kojemu su očitane dobivene vrijednosti. Intenzitet boje izravno je proporcionalan koncentraciji kalcija u uzorku sline. Dobivene vrijednosti unesene su u formulu (13):

Koncentracija kalcija $=$ SA Abs $/ \mathrm{ST}$ Abs x10 = mg kalcija $/ \mathrm{dL}$

SA Abs - apsorbancija uzorka

ST Abs - standardna apsorbancija

SA Abs / ST Abs x 10 - apsorbancija uzorka x 10 apsorbancije standarda

Dobivene su vrijednosti prikazane u tablicama.

Koncentracija fosfata odredila se molibdenskom reakcijom prema spektrofometrijskoj metodi Goldenberga i Fernandeza modificiranoj prema Bardowu i suradnicima (13). Slini se dodao pufer [reakcijska smjesa koju čini 10-postotna trikloroctena kiselina (TCA), 1-postotna urea i 3-postotna Mohrova sol]. Pufer je pripremljen u laboratoriju neposredno prije primjene. Nakon 10 minuta obavljeno je centrifugiranje (Tehtnica Centric 200R, Domel, Železniki, Slovenija) na 5000 okretaja, odvojen je supernatant kojemu je dodana koncentrirana sumporna kiselina i 4,5-postotni amonijev molibdat. Pripravak je držan 20 minuta na sobnoj temperaturi te su zatim spektrofotometrijski odredene vrijednosti apsorpcije u području od $700 \mathrm{~nm}$. Standardna krivulja izrađena je u rasponu od 0 do $10 \mu \mathrm{mol} / \mathrm{L}$ fosfata.

Koncentracija bikarbonata određrena je titracijom s 0,1 $\mathrm{M} \mathrm{HCl}-\mathrm{a}$ u rasponu od $\mathrm{pH} 7$ do $\mathrm{pH} 3$, dodavanjem korovodične kiseline uzorku u volumenu od $100 \mu \mathrm{L}$. U spomenutoj otopini izmjerena je titrirana slina i zabilježena je dobivena vrijednost. Nakon mjerenja su dobivene vrijednosti unesene $\mathrm{u}$ formulu i dobivena je konačna vrijednost. Formula korištena za izračunavanje bikarbonata bila je:

$\mathrm{C}^{1} \mathrm{~V}^{1}=\mathrm{C}^{2} \mathrm{~V}^{2}$ 
$\mathrm{C}^{1} \mathrm{~V}^{1}=\mathrm{C}^{2} \mathrm{~V}^{2}$

$\mathrm{C}^{1}$ - acid concentration

$\mathrm{C}^{2}$ - the unknown value that we are looking for,

$\mathrm{V}^{1}$ - total titration agent volume,

$\mathrm{V}^{2}$ - total volume (saliva and titration agent)

We divided the obtained $\mathrm{C}^{2}$ value by $\Delta \mathrm{pH}$, which represents the difference between the first $\mathrm{pH}$ sample and the last $\mathrm{pH}$ sample measured. Values were expressed in $\mathrm{mmol} / \mathrm{L}$. All values obtained from saliva samples were documented in the questionnaire for each patient individually.

\section{Statistical analysis}

A two-way-test (Student's test) was used to compare the values of the variables under the following assumptions: the variances of the compared data groups are unequal and the difference of the mean values of the variables being compared is equal to zero. The differences were considered significant at $\mathrm{P}<0.05$. Standard descriptive statistics tools (frequency tables, grouping of data into classes, graphs, calculation of arithmetic mean and minimum and maximum values, standard deviation and variance) were used to display and analyze the data obtained by the research.

\section{Results}

The values obtained by measuring the amount of saliva and calcium, phosphate and bicarbonate ion concentration in patient and control subjects in stimulated and resting saliva are presented in Tables 1-4 and Figures 1-4.

The average amount of saliva of the stimulated and resting saliva in patient and control subjects is presented in Table 1 and Figure 1. The results obtained show a statistically significant difference in the amount of non-stimulated saliva excreted between the subjects from the patient $(1.739 \mathrm{~mL} / 5$ $\mathrm{min}$ ) and control groups $(3.535 \mathrm{~mL} / 5 \mathrm{~min})(\mathrm{p}: 0.00018$, $\mathrm{p}<0.05)$, as well as in stimulated saliva where there is a statistically significant difference between the two groups (3.594 $\mathrm{mL} / 5 \mathrm{~min} / 6.271 \mathrm{~mL} / 5 \mathrm{~min}$ ) (p: 0.00048, $\mathrm{p}<0.05$ ).

The calcium concentration values in stimulated and nonstimulated saliva in patient and control groups are presented in Table 2 and Figure 2. In non-stimulated saliva, there is a statistically significant difference between the average values of patient $(6.143 \mathrm{mg} / \mathrm{dL})$ and control subjects $(7.922 \mathrm{mg} /$ dL) (p: $0.03, p<0.05)$, while there is no statistically signifi-
$\mathrm{C}^{1}$ - koncentracija kiseline

$\mathrm{C}^{2}$ - nepoznata vrijednost koja se traži

$\mathrm{V}^{1}$ - ukupni volumen titracijskog sredstva

$\mathrm{V}^{2}$ - ukupni volumen (slina i titracijsko sredstvo)

Dobivena vrijednost $\mathrm{C}^{2}$ podijeljena je $s \Delta \mathrm{pH}$, što predstavlja razliku između prvoga i posljednjega mjerenja $\mathrm{pH}$ na istom uzorku. Vrijednosti su izražene u mmol/L. Sve vrijednosti dobivene iz uzoraka sline dokumentirane su u upitniku za svakog pacijenta pojedinačno.

\section{Statistička analiza}

Za usporedbu vrijednosti varijabli korišten je dvosmjerni test (Studentov test), a pretpostavke su bile sljedeće: varijance uspoređenih skupina podataka nejednake su i razlika srednjih vrijednosti varijabli koje se uspoređuju jednaka je nuli. Razlike su se smatrale značajnima kada je $\mathrm{P}<0,05$. Za prikaz i analizu podataka dobivenih istraživanjem korišteni su standardni opisni statistički alati (tablice učestalosti, grupiranje podataka u razrede, grafovi, izračun aritmetičke sredine te najniže i najviše vrijednosti, standardno odstupanje i varijanca).

\section{Rezultati}

Vrijednosti dobivene mjerenjem količine koncentracije sline te kalcijevih, fosfatnih i bikarbonatnih iona bolesnika $\mathrm{i}$ ispitanika u kontrolnoj skupini, u stimuliranoj i nestimuliranoj slini prikazane su u tablicama od 1 do 4 i na slikama od 1 do 4 .

Prosječna količina stimulirane i nestimulirane sline pacijenata i sudionika u kontrolnoj skupini prikazana je u tablici 1. i na slici 1. Dobiveni rezultati pokazuju statistički značajnu razliku u količini izlučene nestimulirane sline između pacijenta $(1,739 \mathrm{~mL} / 5 \mathrm{~min}$.) i kontrolne skupine $(3,535 \mathrm{~mL} / 5$ min.) (p: 0,00018, p < 0,05) te u količini stimulirane sline gdje postoji statistički značajna razlika između tih dviju skupina $(3,559 \mathrm{~mL} / 5 \mathrm{~min} . ; 6,271 \mathrm{~mL} / 5 \mathrm{~min}$.) (p: 0,00048, p < $0,05)$.

Vrijednosti koncentracije kalcija u stimuliranoj i nestimuliranoj slini pacijenata i sudionika u kontrolnoj skupini prikazane su u tablici 2 i na slici 2 . U nestimuliranoj slini uočena je statistički značajna razlika između prosječnih vrijednosti dobivenih od pacijenata $(6,143 \mathrm{mg} / \mathrm{dL})$ i sudioni-

Table 1 Amount of excreted saliva.

Tablica 1. Količina izlučene sline

\begin{tabular}{|c|c|c|c|c|}
\hline \multirow[b]{2}{*}{ Saliva amount (ml/5 min) } & \multicolumn{2}{|c|}{ Non-stimulated saliva } & \multicolumn{2}{|c|}{ Stimulated saliva } \\
\hline & $\begin{array}{l}\text { Experimental } \\
\text { (N) }\end{array}$ & $\begin{array}{l}\text { Control } \\
\text { (N) }\end{array}$ & $\begin{array}{l}\text { Experimental } \\
\text { (S) }\end{array}$ & $\begin{array}{l}\text { Control } \\
\text { (S) }\end{array}$ \\
\hline Total number & 31 & 31 & 31 & 31 \\
\hline Average value & 1.739 & 3.535 & 3.594 & 6.271 \\
\hline Min value & 0.400 & 1.000 & 0.500 & 2.200 \\
\hline Max value & 5.800 & 8.300 & 11.000 & 11.200 \\
\hline St. deviation & 1.30810 & 1.82365 & 2.73982 & 2.63947 \\
\hline Variation coefficient & $75.23 \%$ & $51.58 \%$ & $76.24 \%$ & $42.097 \%$ \\
\hline
\end{tabular}


Table 2 Calcium ion concentration value in stimulated and non-stimulated saliva excreted.

Tablica 2. Vrijednost koncentracije kalcijevih iona u izlučenoj stimuliranoj i nestimuliranoj slini

\begin{tabular}{|c|c|c|c|c|}
\hline \multirow[b]{2}{*}{$\mathrm{Ca}(\mathrm{mg} / \mathrm{dl})$} & \multicolumn{2}{|c|}{ Non-stimulated saliva } & \multicolumn{2}{|c|}{ Stimulated saliva } \\
\hline & Experimental (N) & Control (N) & $\begin{array}{c}\text { Experimental } \\
\text { (S) }\end{array}$ & Control (S) \\
\hline Total number & 31 & 31 & 31 & 31 \\
\hline Average value & 6.143 & 7.922 & 5.911 & 6.541 \\
\hline Min value & 0.917 & 0.464 & 1.409 & 3.217 \\
\hline Max value & 14.173 & 13.805 & 12.987 & 12.481 \\
\hline St. deviation & 3.53591 & 2.87808 & 3.10942 & 2.11706 \\
\hline Variation coefficient & $57.56 \%$ & $36.33 \%$ & $52.60 \%$ & $32.37 \%$ \\
\hline
\end{tabular}

Table 3 Phosphate ion concentration value in stimulated and non-stimulated saliva. Tablica 3. Vrijednost koncentracije fosfatnih iona u stimuliranoj i nestimuliranoj slini

\begin{tabular}{|c|c|c|c|c|}
\hline \multirow[b]{2}{*}{ Phosphates ( $\mu \mathrm{mol} / \mathrm{l})$} & \multicolumn{2}{|c|}{ Non-stimulated saliva } & \multicolumn{2}{|c|}{ Stimulated saliva } \\
\hline & $\begin{array}{c}\text { Experimental } \\
\text { (N) }\end{array}$ & $\begin{array}{l}\text { Control } \\
\text { (N) }\end{array}$ & $\begin{array}{l}\text { Experimental } \\
\text { (S) }\end{array}$ & $\begin{array}{l}\text { Control } \\
\text { (S) }\end{array}$ \\
\hline Total number & 31 & 31 & 31 & 31 \\
\hline Average value & 2.818 & 1.388 & 1.454 & 0.565 \\
\hline Min value & 0.109 & 0.054 & 0.018 & 0.018 \\
\hline Max value & 17.636 & 3.254 & 5.927 & 3.690 \\
\hline St. deviation & 3.51657 & 1.07435 & 1.47937 & 0.77418 \\
\hline Variation coefficient & $124.79 \%$ & $77.41 \%$ & $101.77 \%$ & $137.02 \%$ \\
\hline t value & \multicolumn{2}{|c|}{0.037135} & \multicolumn{2}{|c|}{0.004839} \\
\hline
\end{tabular}

Table 4 Bicarbonate ion concentration value in stimulated and non-stimulated saliva.

Tablica 4. Vrijednost koncentracije bikarbonatnih iona u stimuliranoj i nestimuliranoj slini

\begin{tabular}{|c|c|c|c|c|}
\hline \multirow[b]{2}{*}{ Bicarbonates $(\mathrm{mmol} / \mathrm{l})$} & \multicolumn{2}{|c|}{ Non-stimulated saliva } & \multicolumn{2}{|c|}{ Stimulated saliva } \\
\hline & $\begin{array}{l}\text { Experimental } \\
(\mathrm{N})\end{array}$ & $\begin{array}{l}\text { Control } \\
\text { (N) }\end{array}$ & Experimental $(S)$ & $\begin{array}{l}\text { Control } \\
(S)\end{array}$ \\
\hline Total number & 31 & 31 & 31 & 31 \\
\hline Average value & 14.041 & 9.929 & 10.872 & 5.964 \\
\hline Min value & 2.939 & 2.890 & 2.562 & 2.467 \\
\hline Max value & 37.131 & 29.600 & 38.300 & 10.219 \\
\hline St. Deviation & 9.48100 & 5.07875 & 9.41473 & 2.47299 \\
\hline Variation coefficient & $67.53 \%$ & $51.15 \%$ & $86.59 \%$ & $41.47 \%$ \\
\hline $\mathrm{t}$ value & \multicolumn{2}{|c|}{0.03870} & \multicolumn{2}{|c|}{0.00819} \\
\hline
\end{tabular}

cant difference between the two groups in stimulated saliva $(5.911 \mathrm{mg} / \mathrm{dL} / 6.541 \mathrm{mg} / \mathrm{dL})(\mathrm{p}: 0.35, \mathrm{p}>0.05)$.

The average phosphate concentration values in nonstimulated and stimulated saliva in patient and control subjects are presented in Table 3 and Figure 3. In non-stimulated $(2.818 \mathrm{mmol} / \mathrm{L} / 1.388 \mathrm{mmol} / \mathrm{L})(\mathrm{p}: 0.03, \mathrm{p}<0.05)$ and stimulated saliva $(1.454 \mathrm{mmol} / \mathrm{L} / 0.565 \mathrm{mmol} / \mathrm{L})(\mathrm{p}: 0.004$, $\mathrm{p}<0.05)$ there are statistically significant differences in the average values between patient and control groups.

The bicarbonate concentration value in resting and stimulated saliva in patient and control groups is presented in Table 4 and Figure 4. In non-stimulated $(14.041 \mathrm{mmol} / \mathrm{L}$ ka u kontrolnoj skupini $(7,922 \mathrm{mg} / \mathrm{dL})(\mathrm{p}: 0,03, \mathrm{p}<0,05)$, a nema statistički značajne razlike između dviju skupina u stimuliranoj slini $(5,911 \mathrm{mg} / \mathrm{dL} ; 6,541 \mathrm{mg} / \mathrm{dL})(\mathrm{p}: 0,35$, pa> $0,05)$.

Prosječne vrijednosti koncentracije fosfata u nestimuliranoj i stimuliranoj slini pacijenata i sudionika u kontrolnoj skupini prikazane su u tablici 3 i na slici 3 . U nestimuliranoj slini $(2,818 \mathrm{mmol} / \mathrm{L} ; 1,388 \mathrm{mmol} / \mathrm{L})(\mathrm{p}: 0,03, \mathrm{p}<0,05)$ i stimuliranoj $(1,445 \mathrm{mmol} / \mathrm{L} ; 0,565 \mathrm{mmol} / \mathrm{L})(\mathrm{p}: 0,004, \mathrm{p}$ $<0,05$ ) zabilježene su statistički značajne razlike u prosječnim vrijednostima između pacijenata i sudionika u kontrolnoj skupini. 


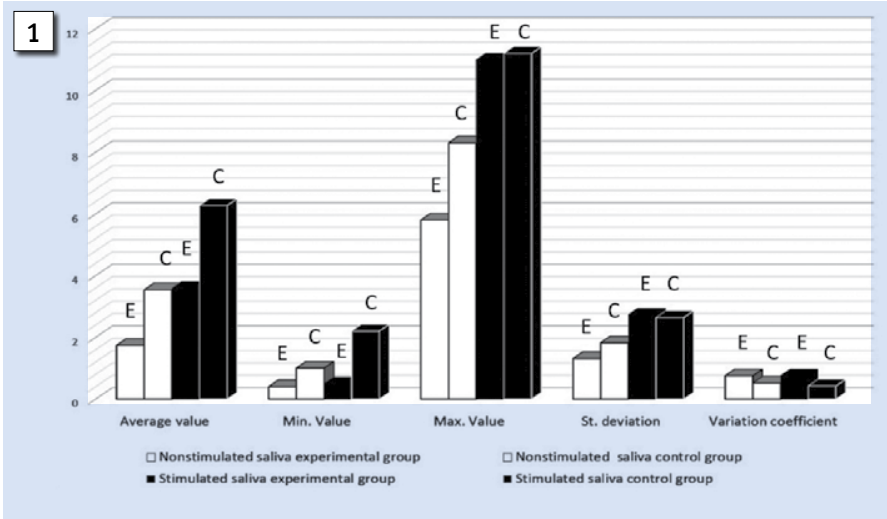

\section{2}
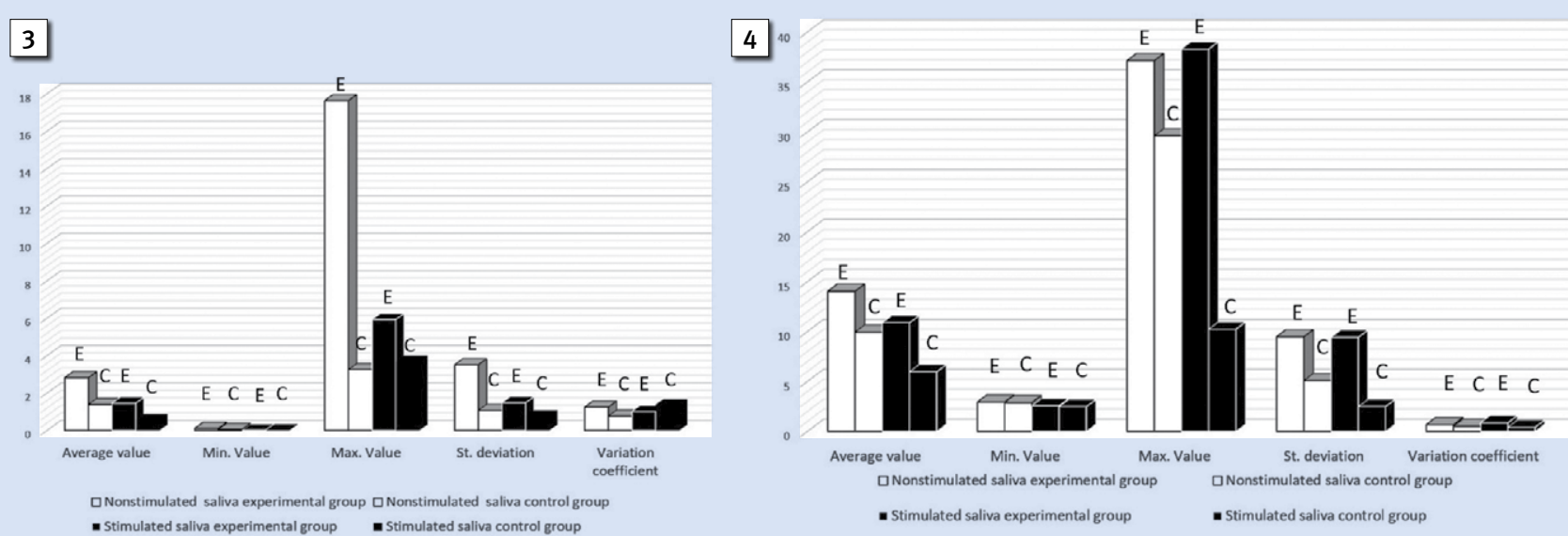

Figure 1 The average amount of non-stimulated and stimulated saliva in the experimental and control group (E- experimental group, C- control group).

Slika 1. Prosječna količina nestimulirane i stimulirane sline u eksperimentalnoj i kontrolnoj skupini (E - eksperimentalna skupina; C kontrolna skupina)

Figure 2 The average calcium concentration value in non-stimulated and stimulated saliva in the experimental and control group (Eexperimental group, C- control group).

Slika 2. Prosječna vrijednost koncentracije kalcija u nestimuliranoj i stimuliranoj slini u eksperimentalnoj i kontrolnoj skupini (E eksperimentalna skupina; C - kontrolna skupina)

Figure 3 The average phosphate concentration value in non-stimulated and stimulated saliva in experimental and control group (Eexperimental group, C- control group).

Slika 3. Prosječna vrijednost koncentracije fosfata u nestimuliranoj i stimuliranoj slini u eksperimentalnoj i kontrolnoj skupini (E eksperimentalna skupina; $C$ - kontrolna skupina)

Figure 4 The average bicarbonate ion concentration value in non-stimulated and stimulated saliva in experimental and control group (Eexperimental group, C- control group).

Slika 4. Prosječna vrijednost koncentracije bikarbonata u nestimuliranoj i stimuliranoj slini u eksperimentalnoj i kontrolnoj skupini (E eksperimentalna skupina; $\mathrm{C}-$ kontrolna skupina)

/ $9.929 \mathrm{mmol} / \mathrm{L})(\mathrm{p}: 0.03, \mathrm{p}<0.05)$ and in stimulated saliva $(10.872 \mathrm{mmol} / \mathrm{L} / 5.964 \mathrm{mmol} / \mathrm{L})(\mathrm{p}: 0.008, \mathrm{p}<0.05)$, there are statistically significant differences in the average values between the patient and control group subjects.

\section{Discussion}

The qualitative and quantitative features of saliva are related to the biological functions of the entire body and may be related to the emergence and development of both local and several systemic diseases (14-16). The amount of resting saliva in a healthy person under physiological conditions ranges from $0.3 \mathrm{ml} / \mathrm{min}$ to $0.4 \mathrm{~mL} / \mathrm{min}$. In the case of reduced saliva secretion (oligosallium), the amount of saliva excreted ranges from 0.2 to $0.4 \mathrm{~mL} / \mathrm{min}$, and if the values of
Vrijednost koncentracije bikarbonata u nestimuliranoj i stimuliranoj slini pacijenata i sudionika u kontrolnoj skupini prikazana je u tablici 4 i na slici 4 . U nestimuliranoj slini $(14,041 \mathrm{mmol} / \mathrm{L} ; 9,929 \mathrm{mmol} / \mathrm{L})(\mathrm{p}: 0,03, \mathrm{p}<0,05)$ i u stimuliranoj $(10,872 \mathrm{mmol} / \mathrm{L} ; 5,964 \mathrm{mmol} / \mathrm{L})(\mathrm{p}: 0,008, \mathrm{p}<$ $0,05)$ uočene su statistički značajne razlike u prosječnim vrijednostima između pacijenta i sudionika u kontrolnoj skupini.

\section{Rasprava}

Kvalitativni i kvantitativni nalazi sline povezani su s biološkim funkcijama cijelog organizma te mogu biti povezani s pojavom i nastankom kako lokalnih tako i pojedinih sistemskih bolesti $(14-16)$. Količina nestimulirane sline kod zdrave osobe, u fiziološkim uvjetima, kreće se u vrijednostima od $0,3 \mathrm{~mL} / \mathrm{min}$. do $0,4 \mathrm{~mL} / \mathrm{min}$. U slučaju smanjenog izlučivanja sline (oligosalija), količina izlučene sline je od 0,2 do $0,4 \mathrm{~mL} / \mathrm{min}$. a ako su vrijednosti izlučivanja sli- 
saliva excretion are less than $0.2 \mathrm{~mL} / \mathrm{min}$ that is called hyposalivation $(17,18)$.

In this study, a statistically significant difference $(\mathrm{p}=0.000108)$ was found in the average values of the resting saliva excreted in the patient group $(1.739 \mathrm{~mL} / 5 \mathrm{~min})$ compared to the control group $(3.535 \mathrm{~mL} / 5 \mathrm{~min})$. Moreover, a statistically significant difference $(\mathrm{p}=0.00048)$ of the average values of stimulated saliva excreted in the patient group (3.594 $\mathrm{mL} / 5 \mathrm{~min})$, compared to the control group (6.271 $\mathrm{mL} / 5 \mathrm{~min}$ ). These results are consistent with those of Leandro (19), who measured the amount of saliva excreted in patients using beta blockers. Kagawa et al. (20) obtained slightly different results in which there was no difference in the amounts of resting and stimulated saliva excreted in patient and control group. Consistent with our study, Nauntofte and Twetman (21) reported an increase in xerostomia in patients on diuretic therapy. The reduced amount of resting and stimulated saliva excreted in the patient group may be related to the long-term usage of antihypertensive medications, as confirmed by Murray (22) in his study.

Skanda (23) confirmed that there was a close relation between the use of thiazide medication and xerostomia, stating that xerostomia was ten times more enhanced after furosemide ingestion. Cano et al. (24) suggested that renin-angiotensin system mechanisms complying exclusively vasoconstriction and dilation are not able to completely describe salivary glands local mechanisms on saliva release, since the decrease of angiotensin converting enzyme expression in myoepithelial cells cannot explain lower salivary rates by itself. They considered that local angiotensin converting enzyme, in addition to other cascades, would affect these cells contraction and further reduce saliva flow. In this study, no difference was observed in the administration of certain medication from different groups of antihypertensives in the amount of saliva obtained.

The amount of saliva excreted as well as its physicochemical properties (composition, $\mathrm{pH}$ value), with particular emphasis on calcium and phosphate concentrations, are closely related to the emergence of demineralization and carious lesions in the hard-dental tissue area $(25,26)$.

Calcium concentration values in saliva, on average, under physiological conditions in a healthy person are $8.8-10.5 \mathrm{mg} /$ $\mathrm{dL}$. This study obtained a statistically significant $(\mathrm{p}=0.034)$ average calcium concentration value in resting saliva in patient group $(6.143 \mathrm{mg} / \mathrm{dL})$ compared to control group $(7.922$ $\mathrm{mg} / \mathrm{dL}$ ). Stojšin (27) obtained approximately the same values of average calcium concentration in resting saliva. The average calcium concentration value in stimulated saliva in patient group was $5.911 \mathrm{mg} / \mathrm{dL}$, while in the control group it was $6.541 \mathrm{mg} / \mathrm{dL}$. Although lower values were obtained in the patient group, they were not statistically significant. By comparing the average calcium concentration values in stimulated and resting saliva, higher values were shown in resting saliva in these two groups. Contrary to the results of this this study, Gauri, Nagarajappa, Bhat (28) found a lower average value of $5.87 \mathrm{mg} / \mathrm{dL}$ in resting saliva, whereas after stimulation, the average calcium concentration value was $7.17 \mathrm{mg} /$ dL. Jarvinen (29) in his study obtained a lower calcium and ne manje od 0,2 $\mathrm{mL} / \mathrm{min}$., takvo se stanje naziva hiposalivacija $(17,18)$.

U ovom istraživanju utvrđena je statistički značajna razli$\mathrm{ka}(\mathrm{p}=0,000108) \mathrm{u}$ srednjim vrijednostima količine izlučene nestimulirane sline u skupni pacijenata $(1,739 \mathrm{~mL} / 5 \mathrm{~min}$.) u odnosu prema kontrolnoj skupini $(3,535 \mathrm{~mL} / 5 \mathrm{~min}$.). Također je utvrđena statistički značajna razlika $(\mathrm{p}=0,00048) \mathrm{u}$ srednjim vrijednostima količine izlučene stimulirane sline $\mathrm{u}$ skupini pacijenata $(3,594 \mathrm{~mL} / 5 \mathrm{~min}$. u usporedbi s kontrolnom skupinom $(6,271 \mathrm{~mL} / 5 \mathrm{~min}$.). Ti su rezultati u skladu s rezultatima Leandra (19) koji je mjerio količinu izlučene sline pacijentima koji su se koristili beta-blokatorima. Kagawa i suradnici (20) dobili su nešto drukčije rezultate - nije bilo razlike u količini izlučene nestimulirane i stimulirane sline kod pacijenata i sudionika u kontrolnoj skupini. U skladu s našim istraživanjem, Nauntofte i Twetman (21) izvijestili su o porastu kserostomije kod pacijenata na terapiji diureticima. Smanjena količina nestimulirane i stimulirane sline zabilježena u skupini pacijenata može biti povezana s dugotrajnom primjenom antihipertenzivnih lijekova, što je u svojoj studiji potvrdio Murray (22).

Skanda (23) je istaknuo usku povezanost između primjene tiazidnih lijekova i kserostomije, navodeći da je kserostomija deset puta pojačana nakon uzimanja furosemida. Cano i suradnici (24) sugeriraju da mehanizmi renin-angiotenzinskog sustava koji počivaju isključivo na vazokonstrikciji i dilataciji nisu u stanju potpuno opisati lokalne mehanizme izlučivanja sline u žlijezdama slinovnicama, zato što smanjenje ekspresije enzima pretvarača angiotenzina u mioepitelnim stanicama samo po sebi ne može objasniti smanjene vrijednosti u izlučivanju sline. Oni smatraju da bi lokalni enzim koji djeluje na pretvorbu angiotenzina, uz ostale kaskade, mogao utjecati na kontrakciju tih stanica i dodatno smanjiti protok sline. $U$ ovom istraživanju nije uočena razlika pri primjeni pojedinih lijekova iz različitih skupina antihipertenziva na količinu izlučene sline.

Količina izlučene sline i njezina fizikalno-kemijska svojstva (sastav, $\mathrm{pH}$ vrijednost), s posebnim naglaskom na koncentraciju kalcija i fosfata, usko su povezana s pojavom demineralizacije i karijesnih lezija u području tvrdih zubnih tkiva $(25,26)$.

Vrijednosti koncentracije kalcija u slini, u fiziološkim uvjetima i kod zdrave osobe, prosječno iznose od 8,8 do 10,5 $\mathrm{mg} / \mathrm{dL}$. U ovom istraživanju dobivena je statistički značajna $(\mathrm{p}=0,034)$ prosječna vrijednost koncentracije kalcija $\mathrm{u}$ nestimuliranoj slini u skupini pacijenata $(6,143 \mathrm{mg} / \mathrm{dL}) \mathrm{u}$ usporedbi s kontrolnom skupinom $(7,922 \mathrm{mg} / \mathrm{dL})$. Stojšin (27) je utvrdila približno iste vrijednosti prosječne koncentracije kalcija u nestimuliranoj slini. Prosječna vrijednost koncentracije kalcija u stimuliranoj slini u skupini pacijenata bila je 5,911 mg/dL, a u kontrolnoj skupini iznosila je 6,541 $\mathrm{mg} / \mathrm{dL}$. Iako su u skupini pacijenata dobivene niže vrijednosti, one nisu bile statistički značajne. Usporedbom prosječnih vrijednosti koncentracije kalcija u stimuliranoj i nestimuliranoj slini dobivene su više vrijednosti u stimuliranoj slini u objema ispitivanim skupinama. Suprotno rezultatima u ovoj studiji, Gauri, Nagarajappa i Bhat (28) pronašli su nižu prosječnu vrijednost od $5,87 \mathrm{mg} / \mathrm{dL}$ u nestimuliranoj slini, a po- 
phosphate concentration values in resting saliva, which was explained by the small amount of resting saliva in all study groups. Some studies have shown that critical $\mathrm{pH}$ value (below 5.5) could be modified if calcium and phosphate substituents were added depending on the amount of saliva excreted and the $\mathrm{pH}$ value $(30,31)$.

Phosphate buffer is the dominant buffer in resting saliva. It is a combination of primary and secondary phosphate, where the concentration in resting saliva is $7-8 \mathrm{mM} / \mathrm{L}$, and during the salivation stimulation period, this value decreases to $2-3 \mathrm{mM} / \mathrm{L}$ (32).

The results of the current study showed a statistically significant difference in phosphate concentration value between the patient and control groups, with values higher in resting saliva compared to stimulated saliva. The average phosphate concentration value in resting saliva in the patient group was higher $(2.818 \mu \mathrm{mol} / \mathrm{L})$, compared to the control group $(1.388 \mu \mathrm{mol} / \mathrm{L})(\mathrm{p}<0.05)$. In stimulated saliva, phosphate concentration values were higher in the patient group (1.454 $\mu \mathrm{mol} / \mathrm{l})$ than in the control group $(0.565 \mu \mathrm{mol} / \mathrm{L})$. The higher phosphate concentration obtained in the patient group saliva could have an impact on reducing the frequency of demineralization processes and carious lesions on hard dental tissues. Surdilović (33) found that phosphate concentration values were significantly high in both stimulated and resting saliva in children with low caries risk. In assessing phosphate concentration results in resting saliva, the potentially possible part that remains bound and neutralized by acidic products in the oral cavity should also be considered $(34,35)$.

The physiological values of salivary bicarbonates are between 1-60 mM, with the highest values obtained from the parotid and submandibular gland (36). In this study, a statistically significant difference was found between the bicarbonate concentration values obtained in stimulated and resting saliva in both patient and control group. The bicarbonate concentration is higher in resting saliva in both study groups. It amounts to $14.041 \mathrm{mmol} / \mathrm{L}$ in the patient group, and $9.929 \mathrm{mmol} / \mathrm{L}$ in the control group, while the bicarbonate concentration in stimulated saliva in the patient group is $10.872 \mathrm{mmol} / \mathrm{L}$, and in the control group it is 5.964 $\mathrm{mmol} / \mathrm{L}$. During long-term saliva stimulation, although the amount of the excreted saliva increases, the bicarbonate concentration value decreases, with respect to the total amount, thereby depleting its buffering power, regardless of any further stimulation present. An explanation for the low bicarbonate concentration in stimulated saliva, obtained in this study, could be related to the following factors: the sampling of stimulated saliva that was performed in the early morning, where patients did not take any water or food; chewing paraffin without taste that was used as a stimulating agent; and the intensity of the chewing cycles that were done. Bardow et al. (37) pointed out that the amount of bicarbonate in the saliva depends on the total amount of saliva excreted. In their study, Bardow, Nyvad and Nauntofte (38) emphasized that bicarbonate concentration in saliva is dependent on the flow rate and on the intensity of the stimulation applied. They also noticed that different values of the obtained concentrations are related to the number of chewing cycles. slije stimulacije je prosječna vrijednost koncentracije kalcija bila $7,17 \mathrm{mg} / \mathrm{dL}$. Jarvinen (29) je u svojoj studiji dobio niže vrijednosti koncentracije kalcija i fosfata u nestimuliranoj slini, što je objašnjeno malom količinom nestimulirane sline u svim ispitivanim skupinama. Studije su pokazale da bi se kritična $\mathrm{pH}$ vrijednost (niža od 5,5) mogla izmijeniti ako bi se dodali supstituenti kalcija i fosfata, a ovisno o količini izlučene sline i njezinoj $\mathrm{pH}$ vrijednosti $(30,31)$.

Fosfatni pufer je dominantan u nestimuliranoj slini. To je kombinacija primarnog i sekundarnog fosfata, gdje koncentracija u stimuliranoj slini iznosi od 7 do $8 \mathrm{mM} / \mathrm{L}$, a tijekom stimulacije salivacije ta se vrijednost smanjuje na 2 do $3 \mathrm{mM} / \mathrm{L}$ (32).

Rezultati studije pokazali su statistički značajnu razliku u vrijednosti koncentracije fosfata između pacijenta i kontrolne skupine, $s$ vrijednostima višima u nestimuliranoj slinu u usporedbi sa stimuliranom. Prosječna vrijednost koncentracije fosfata u nestimuliranoj slini u skupini pacijenata bila je viša $(2,818 \mu \mathrm{mol} / \mathrm{L}) \mathrm{u}$ usporedbi s kontrolnom skupinom $(1,388$ $\mu \mathrm{mol} / \mathrm{L})(\mathrm{p}<0,05)$. U stimuliranoj slini vrijednosti koncentracije fosfata bile su više u skupini pacijenata $(1,445 \mu \mathrm{mol} / \mathrm{L})$ u odnosu prema kontrolnoj skupini $(0,565 \mu \mathrm{mol} / \mathrm{L})$. Veća koncentracija fosfata dobivena u slini skupine pacijenata mogla bi utjecati na smanjenje učestalosti procesa demineralizacije i karijesnih lezija na tvrdim zubnim tkivima. Šurdilović (33) je utvrdio da su vrijednosti koncentracije fosfata kod djece $s$ niskim rizikom od karijesa bile značajno povišene i u stimuliranoj i u nestimuliranoj slini. Pri procjeni rezultata koncentracije fosfata u nestimuliranoj slini također treba uzeti u obzir mogući dio koji ostaje vezan i neutraliziran kiselim spojevima u usnoj šupljini $(34,35)$.

Fiziološke vrijednosti bikarbonata u slini kreću se između 1 i $60 \mathrm{mM}$, a najviše vrijednosti dobivene su iz parotidne i submandibularne žlijezde (36). U ovom istraživanju zabilježena je statistički značajna razlika između vrijednosti koncentracije bikarbonata dobivenih u stimuliranoj i nestimuliranoj slini i u skupini pacijenata i u kontrolnoj skupini. Koncentracija bikarbonata veća je u nestimuliranoj slini u objema ispitivanim skupinama i iznosi $14,041 \mathrm{mmol} / \mathrm{L}$ u skupini pacijenata i 9,929 mmol/L u kontrolnoj skupini, a koncentracija bikarbonata u stimuliranoj slini u skupini pacijenata je 10,872 $\mathrm{mmol} / \mathrm{L}$ i u kontrolnoj skupini $5,964 \mathrm{mmol} / \mathrm{L}$. Tijekom dugotrajne stimulacije, iako se količina izlučene sline povećava, vrijednost koncentracije bikarbonata smanjuje se u odnosu prema ukupnoj količini, čime se iscrpljuje njezina puferska moć, bez obzira na daljnju stimulaciju. Objašnjenje za nisku koncentraciju bikarbonata u stimuliranoj slini, dobiveno u ovoj studiji, moglo bi se povezati s nekoliko čimbenika - uzimanjem uzoraka stimulirane sline koje je obavljeno rano ujutro pri čemu pacijenti nisu uzimali vodu ili hranu, žvakanjem parafina bez okusa koji se koristio kao stimulativno sredstvo i intenzitetom izvedenih ciklusa žvakanja. Bardow i suradnici (37) istaknuli su da količina bikarbonata u slini ovisi o ukupnoj količini izlučene sline. Bardow, Nyvad i Nauntofte (38) u svojoj su studiji istaknuli da koncentracija bikarbonata u slini ovisi o brzini protoka i o intenzitetu primijenjene stimulacije. Također su uočili različite vrijednosti dobivenih koncentracija u odnosu prema broju ciklusa žvakanja. 
Qualitative changes, especially a decrease in calcium ion concentration, can greatly affect possible emergence of demineralization and carious lesions on hard dental tissues. On the contrary, the increased phosphate and bicarbonate ion concentration can stimulate the process of remineralization of hard dental tissues.

\section{Conclusions}

With the limitation of this study, it can be concluded that in patients who have been on continuous antihypertensive therapy for five years or more, compared to the healthy population, a reduced salivation with calcium ions deficiency can be expected, which can lead to increased demineralization of hard dental tissues, and contribute to plaque formation and carious lesions. In order to prevent such processes, it is necessary to compensate for the lack of excreted amount of saliva and calcium ions by implementation of effective prevention programs. On the contrary, the increase in the phosphate and bicarbonate ion concentration in the patient group affects the regulation of acid-base balance and remineralization process, i.e. hard dental tissue preservation, and thus has a preventive effect.

\section{Conflict of interest}

There are no conflicts of interest to declare.

\section{Author's contribution:}

R.A. - coordinated the whole research, participated in clinical sample collection, did the statistics and wrote the article; B.P. - participated in planning of the study, reviewed and prepared the article for publishing; N.T. - participated in clinical part of the research and reviewed selected scientific literature; O.J. - participated in clinical parts of the research and analyzed the data obtained by measurement; V.V. - participated in preparation of individual samples for laboratory analysis and analyzed the results.
Kvalitativne promjene, posebno smanjena koncentracija kalcijevih iona, uvelike utječu na moguću pojavu demineralizacije i karijesnih lezija na tvrdim zubnim tkivima. Suprotno tomu, povećana koncentracija fosfata i bikarbonatnih iona može potaknuti proces remineralizacije tvrdoga zubnog tkiva.

\section{Zaključak}

Uz ograničenja u ovoj studiji, može se zaključiti da se kod pacijenata koji su pet i više godina na kontinuiranoj antihipertenzivnoj terapiji, a u usporedbi sa zdravom populacijom, može očekivati smanjeno izlučivanje sline i nedostatak kalcijevih iona, što može pojačati nastanak demineralizacije tvrdih zubnih tkiva te pridonijeti većoj mogućnosti stvaranja plaka i karijesnih lezija. U svrhu sprječavanja takvih procesa potrebno je preventivnim programom nadoknaditi nedostatak izlučene količine sline i kalcijevih iona. Suprotno navedenomu, povećanje koncentracije fosfatnih i bikarbonatnih iona u skupini pacijenata utječe na regulaciju acido-bazne ravnoteže i proces remineralizacije, $t j$. na očuvanje tvrdoga zubnog tkiva te na taj način djeluje preventivno.

\section{Sukob interesa}

Autori nisu bili u sukobu interesa.

\section{Doprinos autora}

R. A. - koordinirala cijelo istraživanje, sudjelovala u prikupljanju kliničkih uzoraka, radila statistiku i napisala članak; B. P. - - sudjelovao u planiranju studije, pregledao i pripremio članak za objavljivanje; N. T. - sudjelovala u kliničkom dijelu istraživanja i pregledavala odabranu znanstvenu literaturu; O. J. - sudjelovala u kliničkom dijelu istraživanja i analizirala podatke dobivene mjerenjem; V. V. - sudjelovala u pripremi pojedinačnih uzoraka za laboratorijsko istraživanje i analizirala dobivene rezultate.

\section{Sažetak}

Cilj: Cilj istraživanja bio je procijeniti količinu izlučene sline i koncentraciju kalcija, bikarbonata i fosfatnih iona u bolesnika na antihipertenzivnoj terapiji pet i više godina (skupina pacijenata) i usporediti ih s kontrolnom skupinom. Materijal i metode: Skupina pacijenata, ili eksperimentalna skupina, obuhvaćala je 31 ispitanika koji su bili hospitalizirani u Kardiovaskularnoj klinici i bili su na antihipertenzivnoj terapiji lijekovima dulje od pet godina. U kontrolnoj skupini bila je 31 zdrava osoba. Izmjerena količina sline dalje je korištena za određivanje vrijednosti koncentracije kalcijevih, fosfatnih i bikarbonatnih iona. Kalcijevi i fosfatni ioni određivani su spektrofotometrijski, a bikarbonatni ioni titracijom. Rezultati: Za usporedbu vrijednosti varijabli korišten je dvosmjerni test (Studentov test). Količina izlučene sline bila je statistički značajno niža u skupini s pacijentima kojima je uzeta nestimulirana $(1,739 \mathrm{~mL} / 5 \mathrm{~min}$.) i stimulirana slina $(3,559 \mathrm{~mL} / 5 \mathrm{~min}$.). Koncentracija kalcijevih iona statistički je bila značajno niža u skupini pacijenata s nestimuliranom slinom $(6,143 \mathrm{mg} / \mathrm{dL})$. Koncentracija bikarbonata i fosfatnih iona u skupini pacijenata bila je statistički značajno veća u nestimuliranoj (bikarbonatni ion $=14,041 \mathrm{mmol} / \mathrm{L}$, fosfatni ion $=2,818 \mu \mathrm{mol} / \mathrm{L}$ ) i stimuliranoj slini (bikarbonatni ion $=10,872 \mathrm{mmol} / \mathrm{L}$, fosfatni ion $=1,454 \mu \mathrm{mol} / \mathrm{L}$ ). Zaključak: Smanjena količina izlučene sline i kalcijevih iona upućuje na moguću veću učestalost procesa demineralizacije tvrdoga zubnog tkiva. Suprotno tomu, povećanje koncentracije fosfatnih i bikarbonatnih iona u skupini pacijenata utječe na regulaciju acido-bazne ravnoteže i na taj način djeluje preventivno.
Zaprimljen: 4. kolovoza 2020.

Prihvaćen: 16. studenoga 2020.

Adresa za dopisivanje

Božidar Pavelić, redoviti profesor

Zavod za endodonciju i restaurativnu stomatologiju

Stomatološki fakultet Sveučilišta u

Zagrebu

Gundulićeva 5

10000 Zagreb, Hrvatska

tel: +385 (0)1 4802136

pavelic@sfzg.hr

Ključne riječi

antihipertenzivi; dugotrajni neželjeni učinci; lučenje sline; bikarbonati; kalcij; Fosfor 


\section{References}

1. Dawod IM, El-Samarrai SK. Saliva and Oral Health. Int J Adv Res Biol Sci. 2018;5(7):1-45.

2. Cydejko A, Kusiak A, Grzybowska ME, Kochańska B, Ochocińska J, Maj A, et al. Selected physicochemical properties of saliva in menopausal women - a pilot study. Int J Environ Res Public Health. 2020 Apr 10;17(7):2604-11.

3. Ivanovski K. The Impact of Antihypertensive Medications on Quantitative and Qualitative Characteristics of Saliva. Res J Pharm Biol Chem Sci. 2015;6:1356-64.

4. Xu F, Laguna L, Sarkar A. Aging-related changes in quantity and quality of saliva: Where do we stand in our understanding? J Texture Stud. 2019 Feb;50(1):27-35.

5. Sim CPS, Walker GD, Manton DJ, Soong YL, Wee JTS, Adams GG, et al. Anticariogenic efficacy of a saliva biomimetic in head-and neck cancer patients undergoing radiotherapy. Aust Dent J. 2019 Mar;64(1):47-54.

6. Shumna TY, Voznyi OV, Lepetchenko YS. Determination of electrolyte composition of saliva and calcium level in blood of children with bronchial asthma. Pediatr Pol. 2020;95(1):14-7.

7. Baumann T, Bereiter R, Lussi A, Carvalho TS. The effect of different salivary calcium concentrations on the erosion protection conferred by the salivary pellicle. Sci Rep. 2017 Oct 11;7(1):12999.

8. Deng J, Jackson L, Epstein JB, Migliorati CA, Murphy BA. Dental demineralization and caries in patients with head and neck cancer. Oral Oncol. 2015;51:824-31.

9. Epstein JB, Villines DC, Singh M, Papas A. Management of dry mouth: Assessment of oral symptoms after use of a polysaccharide-based oral rinse. Oral Surg Oral Med Oral Path Oral Radiol. 2017;123:76-83.

10. Ouanounou A. Xerostomia in the geriatric patient: Causes, oral manifestations, and treatment. Compend Contin Educ Dent. 2016 May;37(5):306-311.

11. Tanasiewicz M, Hildebrandt T, Obersztyn I. Xerostomia of various etiologies: A review of the literature. Adv Clin Exp Med. Jan-Feb 2016;25(1):199-206.

12. Silva IVG, de Figueiredo RC, Rios DRA. Effect of Different Classes of Antihypertensive Drugs on Endothelial Function and Inflammation. Int J Mol Sci. 2019 Jul 14;20(14):3458-73.

13. Bardow A, Moe D, Nyvad B, Nauntofte B. The buffer capacity and buffer systems of human whole saliva measured without loss of CO2. Arch Oral Biol. 2000 Jan;45(1):1-12.

14. Družijanić A, Glavina A, Draganja M, Biočina-Lukenda D, Cigić L. Inflammatory Markers and Incidence of other Autoimmune Diseases in Patients with Oral Lichen Planus. Acta Stomatol Croat. 2019 Dec;53(4):363-70.

15. Špiljak B, Šimunović L, Lapić I, Rogić D, Špalj S, Vuletić L. Influence of saliva on the results of global laboratory coagulation tests. Aust Dent J. 2020 Feb 18.

16. Jurela A, Verzak Ž, Brailo V, Škrinjar I, Sudarević K, Janković B. Salivary Electrolytes in Patients with Metallic and Ceramic Orthodontic Brackets. Acta Stomatol Croat. 2018 Mar;52(1):32-6.

17. Lan X, Chan JYK, Pu JJ, Qiao W, Pang S, Yang W, et al. Saliva electrolyte analysis and xerostomia-related quality of life in nasopharyngeal carcinoma patients following intensity-modulated radiation therapy. Radiother Oncol. 2020 Sep;150:97-103.

18. Bert-Couto SA, Couto-Souza PH, Jacobs R. Clinical diagnosis of hyposalivation in hospitalized patients. J Appl Oral Sci. Mar-Apr 2012;20(2):157-61.
19. Leandro FM. Relationships of beta-blockers and anxiolytics intake and salivary secretion, masticatory performance and taste perception. Arch Oral Biol. 2010 Feb;55(2):164-9.

20. Kagawa R. Influence of hypertension on $\mathrm{pH}$ of saliva in older adults. Oral Dis. 2013 Jul;19(5):525-9.

21. Nauntofte B, Twetman S. Effects of furosemide and bendroflumethiazide on saliva flow rate and composition. Arch Oral Biol. 2004 Jul;49(7):507-13.

22. Murray TW. A longitudinal study of medication exposure and xerostomia among older people. J Gerodontol. 2006;23(4):205-13.

23. Skanda R. Xerostomia. J Med Sci Clin Res. 2014;2(3):579-83.

24. Cano IP, Dionisio TJ, Cestari TM, Calvo AM, Colombini-Ishikiriama $\mathrm{BL}$, Faria FAC, et al. Losartan and isoproterenol promote alterations in the local renin-angiotensin system of rat salivary glands. PLoS One. 2019 May 22;14(5):e0217030.

25. Poureslami HR, Tarkzadeh M, Sefadini MR. Study of changes in phosphate, calcium and fluoride ions in plaque and saliva after the administration of a fluoride mouth rinse. J Ind Soc Pedod Prev Dent. 2007;25(3):122-5.

26. Rufi MP, Siddharta V, Girish S, Sameer Z. Estimation and comparison of salivary calcium, phosphorous, alkaline phosphatase and $\mathrm{pH}$ levels in periodontal health and disease:a cross-sectional biochemical study. J Clin Diagn Res. 2016 Jul;10(7):ZC58-61.

27. Stojšin, I. Dental manifestation of gastroesophageal reflux disease (GERD). Serb Dent J. 2007;54:125-31.

28. Gauri K, Nagarajappa R, Bhat N. Evaluation of salivary calcium and phosphorous concentration before and after chewing CPP-ACP containing chewing gum. Acta stomatol Croat. 2012;46(2):117-25.

29. Jarvinen VK. Risk factors in dental erosion. J Dent Res. 1991;70: 942-7.

30. Yasmin M, Eman EM, Hala MED. Salivary carbonic anhydrase, $\mathrm{pH}$ and phosphate buffer concentrations as potential biomarkers in caries risk at children. J Unexplo Med Data. 2017;2:9-15.

31. Gonçavles GK, Carmagnani FG, Corrêa MS, Duarte DA, Santos MT. Dental erosion in cerebral palsy patients. J Dent Child. 2008;75(2):117-20.

32. Rajesh KS, Zareena SH, Kumar MA. Assesment of salivary calcium, phosphate, magnesium, $\mathrm{pH}$ and flow rate in healthy subjects, periodontitis and dental caries. Contemp Clin Dent. Oct-Dec 2015;6(4):461-5

33. Šurdilović D. The importance of saliva phosphate buffer in the evaluation of caries incidence in children. Acta Stom Naissi. 2009;25(59):851-8.

34. Rockenbach MI, Marinho SA, Veeck EB, Lindemann L, Shinkai RS. Salivary flow rate, $\mathrm{pH}$ and concentrations of calcium, phosphate and slgA in Brazilian pregnant and non-pregnant women. Head Face Med. 2006 Nov 28;2:44-8.

35. Navazesh $M$, Christensen CM, Brightman V. Clinical criteria for the diagnosis of salivary gland hypofunction. J Dent Res. 1992;71:1363-9.

36. Bardow A, Madsen J, Nauntofte B. The bicarbonate concentration in human saliva does not exceed the plasma level under normal physiological conditionsClin Oral Investig. 2000 Dec;4(4):245-53.

37. Bardow A, Ten Cate JM, Nauntofte B, Nyvad B. Saliva composition on tooth demineralization:effect on sistemic demineralization. J Dent Res. 2000b;5:244-7.

38. Bardow A, Nyvad B, Nauntofte B. Relationships between medications intake, complaints in dry mouth salivary flow rate and compositions, and the rate of tooth demineralization in situ. Arch Oral Biol. 2001 May;46(5):413-23. 